\title{
An Investigation of Economic Empowerment on Savings: A Case of Women Retailers at the Nakuru County, Kenya
}

\author{
Teresia Atieno Dima, Richard Akuno Nyang'aya \\ Department of Accounting, Finance \& Management Science, Egerton University, Nakuru, Kenya
}

Email address:

dimaterry@yahoo.com (T. A. Dima), roakuno@yahoo.com (R. A. Nyang’aya)

\section{To cite this article:}

Teresia Atieno Dima, Richard Akuno Nyang'aya. An Investigation of Economic Empowerment on Savings: A Case of Women Retailers at the Nakuru County, Kenya. International Journal of Economics, Finance and Management Sciences. Vol. 3, No. 6, 2015 , pp. 657-667. doi: $10.11648 /$ j.ijefm.20150306.11

\begin{abstract}
It is important to save because it significantly influences a person's financial well-being and economic development. Despite its importance, most women farm produce retailers in Nakuru main market do not save. Literature reveals that women's ability to save is affected by their financial empowerment among other factors (Mayoux \& Hartl, 2009). This study investigated the effect of economic empowerment on the savings of women farm produce retailers in Nakuru main market. The study conceptualized that economic empowerment of women affects their level of saving from their business. Age, level of education, marital status and household size were considered to be the moderating factors. The study adopted a descriptive research design. A sample of 65 women selected using stratified, proportionate to size and simple random sampling techniques took part in the study. Data was collected using the women farm produce retailers' questionnaire. Experts from the Department of Accounting, Finance and Management Science, Egerton University examined the face and content validity of the instrument. The reliability of the questionnaire was pilot tested using a sample of 15 women retailers drawn from Shabaab municipal market and the Cronbach alpha method. The data collection tool yielded a reliability coefficient of 0.865 . The data was analyzed with the aid of the Statistical Package for Social Science (SPSS). Hypotheses were tested at the 0.05 level of significance using the Pearson's Correlations, multiple regression and hierarchical regression. The results of the study showed that the independent variables effect on savings was $17.7 \%$, the moderator variables accounted for $4.6 \%$ variation on savings. When the independent variables were added to the equation there was an improvement in $\mathrm{R}^{2}$ from 0.046 to 0.241 . The inclusion of the independent variables in the analysis led to 0.195 change in $\mathrm{R}^{2}$. The governments/NGOs interventions were however not significantly related to savings. The combined effect indicates that there are other factors that affect women's' savings whose broader inclusion and further studies could help reveal.
\end{abstract}

Keywords: Savings, Economic Empowerment, Access

\section{Introduction}

\subsection{Background}

In order to broaden the economic opportunities available to women, it is important to design appropriate financial products that enable them to save and borrow. It is therefore important to understand how womens' access to and control of resources affect their need for capital and their ability to obtain it. It is important that developmental strategies aimed at boosting womens' productive capacity enhance direct access to financial services as this is likely to lead to higher investments in human capital and have important long-term implications for families and societies (Diana \& Lisa, 2011). Although women contribute enormously to economies, they still remain discriminated and exploited. This limits their participation in economic and social policies and curtails access to economic assets such as land and loans. It is therefore important to invest in women's economic empowerment in order to set a direct path towards inclusive economic growth (UNDP, 2013).

To increase their economic opportunities, women need a business climate that supports them in starting and doing business and a financial sector that gives them access to financial services tailored to their needs for example, securing women's land and other property rights, training in production skills and techniques, business management and functional literacy are an important step in their economic empowerment (UNDP, 2015).

Negash (2006) concurs that although women enjoy more 
freedom and power than before, they are still disadvantaged in virtually all aspects of life including equal access to education, capital, and decision making powers in political, social and business sectors. Women in Africa represent 52\% of the total population, contribute approximately $75 \%$ of agricultural work and produce upto $80 \%$ of the food, they earn only $10 \%$ of the African incomes and own just $1 \%$ of the continent's assets. Despite repeated efforts made by governments, NGOs, and multilateral development agencies, the majority of women in the developing world are still relegated to micro enterprises and informal tasks. Consequently, these women working in informal economies are likely to have less access to education, financial capital and land ownership.

There are many impediments to women's economic empowerment and the world has a long way to go to bring women to the forefront of economic participation. Until societies, governments and non-governmental organizations around the world come together and make a concentrated effort to empower and grant equality to women, the world will be stuck in the past, and human well-being will never truly realize its full, vigorous potential.

The problem of women's access to credit was highlighted at the first International Women's Conference in Mexico in 1975, leading to the setting up of Women's World Banking network. In the wake of the second International Women's Conference in Nairobi in 1985, there was a mushrooming of government and non-governmental organizations sponsored income generating programs for women, many of which included savings and credit. In the 1990s, microfinance programs such as the Grameen bank and some affiliates of the Foundation for International Community Assistance (FINCA) began to target women not only because of their poverty alleviation obligation but also because their repayment rates were significantly higher than men's (Mayoux \& Hartl, 2009).

Although savings and investment are important for both personal financial well-being and for economic growth, knowledge and understanding of these concepts is still low in many countries which limits peoples' propensity to save. Despite the importance of saving to economies across the world and the significant barriers to saving, there are no articulated strategies which set out explicit savings goals and means of achieving them. Surveyed governments appeared to use a mix of regulations without any clear idea whether the individual interventions have an impact or whether the mix is right (Lewis and Messy, 2012). Most of the developing countries have witnessed an influx of the number of women venturing in the field of entrepreneurship in recent years; this mainly being attributed to advocacy on women empowerment programs and policies advanced by both government and non-governmental organizations (Eyben, Kabeer, \& Cornwall, 2008).

Women entrepreneurs comprise about a half of human resources in developing economies (World Bank 2009). Many people have difficulty saving as much as they would like. But while households in developed countries have access to many products to help them surmount their saving difficulties, households in developing countries tend to rely on much more informal arrangements (Collins et al. 2009; Rutherford 2000). Enabling small-scale entrepreneurship has long been identified as a mechanism to alleviate poverty, and substantial attention has been paid to micro-credit as a means to promote entrepreneurship. In this context, some have argued that the focus needs to be put on savings instead of credit, since evidence suggests that individuals should be able to save their way out of credit constraints. But this strategy demands accessible opportunities for people to save securely (Pascaline \& Jonathan, 2007). Women's economic empowerment has become increasingly important within the international policies in the recent years.

The formulation of the Beijing Platform for Action and the Millennium Development Goal \#3 on gender equality and women's empowerment adopted an increase in women's share of non-agricultural employment as one of the indicators of women's economic employment (Golla, Malhotra \& Mehra, 2011). The formulation of these two documents paved the way for a greater equation between women's financial empowerment and their access to productive resources (Kabeer, 2012). However, it is not enough for women to earn an income or have access to resources but it is important to know the impact of women's greater access to resources on savings (Esplen, 2007).

According to the United Nations Millennium Campaign, women work two-thirds of the world's working hours, they earn only 10 percent of the world's income and own less than 1 percent of the world's property. Where laws or customs prevent women from owning productive assets, from getting loans or credit, they have no assets to leverage for economic stability and cannot invest in their own or in their children's futures (CARE, 2011). Women usually invest a higher proportion of their earnings in their families and communities. Increasing the role of women in the economy therefore is part of the solution to financial and economic crises and critical for economic resilience and growth (OECD, 2010).

In evaluating the impact of a commitment to micro-savings account, Pitt, Khanker, \& Cartwright (2006) found that micro-finance programmes not only give women access to credit and savings, but reach millions of people worldwide bringing them together regularly in organized groups. Mayoux (2006) added that although no 'magic bullet', they are potentially a very significant contribution to women's financial empowerment. Through their contribution to women's ability to earn an income these programmes have the potential to initiate a series of 'virtuous spirals' of economic empowerment and increased well-being for women.

Women represent half the world's population; therefore to discriminate and prevent half of humanity from reaching its full potential is economic folly which hinders the rest of the world. Thus, concerted actions to educate women, give them equal access to credit and empower them financially are crucial in overcoming the above-mentioned challenges 
(Negash, 2006). Savings has the economic advantage of ability to access loans especially in micro-credit. Commitment to savings positively impacts self-perception of saving behavior and could result in higher bargaining power over withdrawal decisions for women. Women's participation in micro-credit programmes lead to them having greater access to financial resources and freedom of mobility (Pitt et al, 2006).

In Kenya, small enterprises account for about 20 percent of adult employment and 12-14 percent of national GDP, but only 22 percent of micro enterprenuers had savings accounts with commercial bank prior to the study by Wolfgang and Borko, (2013). Although the Government of Kenya, financial institutions and non-governmental organizations have supported the development of women-owned entrepreneurial ventures in Kenya through financial intermediation, infrastructure and policy (GoK, 2005), the women entrepreneurs continue to rely on credit financing for the growth of their businesses instead of mobilizing savings from the business earnings.

Overdependence on loans has affected their operations, performance and realization of their full potential because the loans are costly and inflexible (Ambrose, 2012). Experience has shown that majority of women involved in economic activities that need support do not benefit from the programmes offered by governments. Micro-credit facilities in some cases do not reach the women for enhancement of their production and trade (Ikeduru, 2002). A study by Kato and Kratzer (2013) showed that women members of MFIs have significant control over savings and income generated from the business.

In a study in Rachuonyo District, Rambo (2012) established that economic empowerment is an important contributor to women's savings by noting that women who were economically empowered by doing small businesses were members of savings groups and therefore tended to save as opposed to those who were none members. Savings schemes provide opportunity for low income earners to access affordable financial services which is a critical ingredient for economic empowerment. The study found significant differences between members and non-members of a savings group in terms of amount of capital invested in business, net returns on capital, ownership of land and business premise suggesting that members of a savings group were more likely to be economically empowered than nonmembers. Rutherford 2000; Collins, Jonathan, Stuart, \& Orlanda, (2009) highlighted the demand for small irregular flows to be aggregated into lumpsum sums for household or business investment and that even when formal savings products are unavailable or unaffordable, the poor often save in informal groups.

\subsection{Problem Statement}

Women farm produce retailers in Nakuru Municipality market are predominantly small traders. Some of the women traders are empowered by what credit they access from varied sources, and some from the income they make. A question is asked, do women farm produce retailers save from thei business in respect of their forms of empowerment? Does the financial empowerment they access influence their way and level of saving? This line of thinking and the possible answers to them, could provide a benchmark upon which to understand the interrelationship between the variables; women economic empowerment and their level of saving from their business enterprises. A fundamental concern comes about in respect of the influence of economic empowerment of women on saving. Although many researchers have studied women empowerment, they tend to focus on capacity building modes of empowering women, social welfare, and their participation in income generating activities; but not much exist on the effect of economic empowerment of women on saving in the informal sector (Rambo, 2012). According to Ronald and Edgar (2003) liquidity, degree of safety and returns usually influence a person's choice of medium in which to maintain savings. The ability to provide adequate funds to meet investment needs therefore primarily depends on the savings of individuals and corporations. This research sought to focus on the effect of women financial empowerment on saving in respect of women agricultural produce retailers at the Nakuru main market.

\subsection{Research Objectives}

i. To determine the effects of access to credit on the savings of women farm produce retailers in Nakuru main market

ii. To determine the effects of access to income on the savings of women farm produce retailers in Nakuru main market

iii. To determine the effects of access to Government/Non-Governmental Organizations interventions on the savings of women farm output retailers

iv. To establish the effects of economic empowerment of women on savings from farm produce retailing.

\subsection{Hypotheses of the Study}

$\mathrm{H}_{01}$ : There is no significant relationship between access to credit and the savings of women farm produce retailers in Nakuru main market

$\mathrm{H}_{02}$ : There is no significant relationship between access to income and the savings of women farm produce retailers in Nakuru main market

$\mathrm{H}_{03}$ : There is no significant relationship between access to Government/Non-Governmental Organizations interventions and the savings of women farm produce retailers

$\mathrm{H}_{04}$ : There is no significant effect of access to credit, income and Government/NGOs' interventions on the savings of women farm produce retailers

\section{Literature Review}

\subsection{Brumberg Theory}

Brumberg (2004) ties women's economic empowerment to 
access to affordable financial services. In view of this, women having access to financial services stand a better chance of improving their economic status. The theories assume that access to financial services empowers women by putting capital in their hands, allowing them to earn an independent income and make financial contributions to their households and communities. The theories also assume that involvement in successful income generating activities should translate into greater control and empowerment. Women with economic power often gain control over their lives, contribute directly to their children's nutrition, education and healthcare. It further outlines the indicators of economic empowerment such as income, ownership of properties.

The Brumberg theory therefore supports access to credit and income from productive work as important indicators of women's economic empowerment. However, women's ability to transform their lives through access to financial services depends on factors linked to their personal capabilities, circumstances and the environment within which they operate. The success of women entrepreneurs is further influenced by factors such as access to information, social networks and other resources (Brumberg, 2004). In this respect, Brumberg theory agrees with the economic theory that predicts that savings is as a result of individual characteristics such as income and personal preferences.

The life-cycle hypothesis (Modigliani, 1966) forecasts that individuals hold their spending steady over their lifetime; they save during their working years and draw down their savings in retirement. Franco Modigliani life-cycle theory proposes that consumption and saving reflect on individuals' stage in the life-cycle. In this theory of saving, a nation's wealth gets passed around; the young have little wealth, middle aged people have more and the peak of wealth is reached just before retirement. As they live through their golden years, retirees sell off their assets to provide for their needs. These assets are then taken up by the young who are still in the accumulation stage of the cycle. In an economy where the population is growing, there are more young people than the old therefore; more people are saving other than dissaving. If incomes are growing, the young will be saving on a larger scale than the old dissaving causing a higher savings rate.

According to Deaton (2005), Franco Modigliani's theory of spending was based on the idea that people make intelligent choices about how much they want to spend at each age, limited only by the resources available over their lives. By building up and running down assets, people can tailor their consumption patterns to their needs at different ages independently of their income at each age. This theory leads to two important but non-obvious predictions about the economy as a whole, that national savings depends on the rate of growth of national income, not its level, and that the level of wealth in the economy bears a simple relations to the length of the retirement span.

While there have been many challenges to this theory, it received empirical support in later work by Modigliani and other researchers and therefore life-cycle consumption and saving theory remains essential in the role of saving in economic growth, the effects of demographic change on national saving and the determinants of national wealth.

However, as Deaton (2005) pointed out, the life cycle theory of savings might be of incomplete use in developing economies because wages in many of these nations are unsure and cyclical, making view of longer-term income flows hard; individuals are probable to be credit constrained, so that borrowing in early years will not be easy. This implies that savings in developing nations often plays a significant role in buffering between income and spending. Individuals often save small amounts at regular intervals to smooth income, rather than build up or save for retirement.

\subsection{Access to Credit}

Although the Government of Kenya, financial institutions and non-governmental organizations have supported the development of women-owned entrepreneurial ventures in Kenya through financial intermediation, infrastructure and policy (GoK, 2005), the women entrepreneurs continue to rely on credit financing for the growth of their businesses instead of mobilizing savings from the business earnings. Overdependence on loans has affected their operations, performance and realization of their full potential because the loans are costly and inflexible (Ambrose, 2012). Mukras (2003) recommended provision of soft loans, research for the promotion of appropriate technology and training for entrepreneurs.

A survey of credit market in Kenya by Financial Sector Deepening, FSD (2009) found that, 35\% of Kenyan population depend on informal sources for credit, $19 \%$ of the population access credit from formal banks while $8 \%$ access credit from microfinance institutions. The survey noted that $38 \%$ of the Kenya's population does not have access to credit services. This clearly shows that credit access still remains a challenge to women entrepreneurs who own micro and small enterprises in Kenya. Though commercial banks and Development Finance Institutions (DFIs) have vast financial resources, their impact is yet to be felt by women entrepreneurs, most of whom have no collateral. Women entrepreneurs therefore tend to steer clear because of lack of information, and conditions such as high transaction costs and interest rates averaging above 35 per cent per annum. The findings indicated that most women entrepreneurs, do not access credit from formal sources, especially commercial banks. Other barriers in respect to access to credit may include language; financial obstacles such as high fees or required minimum balances for deposit accounts and lack of appropriate products

\subsubsection{Access to Income}

As income falls, and individuals attempt to maintain the present standard of living, the proportion of consumption spending increases and total savings diminish. Since the basic needs of the individual or the family must be met, personal savings will be eliminated when income is 
drastically reduced and the individual may spend accumulated savings rather than further reduce consumption spending (Ronald \& Edgar, 2003). A report by a partnership of NGOs in Lesotho, Malawi and South Africa showed the importance of informal savings mechanisms throughout the three countries, savings accounts in both formal and informal sectors were often used in a transactional manner with lots of small deposits and transfers, rather than for building lump sums or to earn a return. When households are building lump sums, they are usually doing so based on saving for an identified project such as school fees or farm inputs. These project funds are often used for emergencies if and when they are required (Faurie, 2014).

\subsubsection{Access to Government/NGO Interventions}

In Kenya, small enterprises have been estimated to account for more than 20 percent of adult employment but only 2.2 percent of surveyed micro entrepreneurs had a savings account with a commercial bank prior to the study (Wolfgang \& Borko, 2013). Although the Government of Kenya, financial institutions and non-governmental organizations have supported the development of women-owned entrepreneurial ventures in Kenya through financial intermediation, infrastructure and policy (GoK, 2005), the women entrepreneurs continue to rely on credit financing for the growth of their businesses instead of mobilizing savings from the business earnings. Overdependence on loans has affected their operations, performance and realization of their full potential because the loans are costly and inflexible (Ambrose, 2012).

\subsubsection{Age}

Studies have shown that age positively influences savings. Deaton (2005) noted that contrary to old households, the propensity to consume is higher among the young while their saving is low. Orbeta (2005) observed that savings rate increases with age until the period around retirement, after which it decreases. Ronald and Edgar (2003) concur that individual savings are minimal during youthful years due to low income but increase at middle age as income is higher and the expense of raising children has been reduced or eliminated. At retirement, income is sharply reduced and accumulated savings are drawn up current living expenses. The level of savings of individual is therefore a function of the age composition of the population as a whole. A population shift to a large proportion of individuals in the productive middle-age years would result in greater savings potential. If we have a large number of people moving through their individual life cycles at approximately the same time, their combined efforts will have a major impact on the overall economy because on a collective basis, they spend at about the same time and are also likely to save at about the same time.

\subsubsection{Level of Education}

Riley (2000) pointed out that an entrepreneurs' level of education is directly correlated with his potential for business growth. Education may therefore have an effect on asset accumulation The possible explanation for this is that educational background could be providing applicable skills for running the business. Those with higher levels of education could be in a better position to adapt new business ideas in the current dynamic technological world, hence achieve better entrepreneurial efficiency and effectiveness contributing to positive business growth.

Zhan and Grinstein-Weiss (2005) examined the association between education and savings performances of low-income people in a matched savings program for the poor that targeted low-income people and provided incentives and an institutional structure for saving. Account holders received matching funds as they saved and made a purchase for assets, such as a home, post-secondary education, or microenterprise, that could help promote their long-term well-being Using a data of 2,150 participants, the results indicated a statistically significant relationship between education status and savings. Compared to the participants without a high school degree, those with some college education, especially those with a 4-year college degree, had higher savings. Household income and program characteristics were related to savings outcomes; income and two program factors, monthly savings target and financial education, also partially mediated the relationship between education and savings outcomes.

Sherraden and Beverly (2003) suggested that education is positively associated with savings outcomes of low-income participants in a structured savings program and that the relationship between education and savings were partially mediated by household income, monthly savings target and financial education. In the analysis of data from the Survey of Consumer Finances, Parrish (2004) found that education was positively related to bank account ownership, home ownership, investment, and retirement savings. Educated individuals appeared to have longer time horizons, suggesting that education may alter individual preferences. Yamokoski and Keister, (2004) further suggested several possible ways in which education may affect savings; First, because education is highly related to income, part of the relationship between education and savings may be through income. Second, better educated people may be more future oriented and more likely to have a positive savings attitudes, which may lead to stronger savings motives. Third, education may help improve financial decision-making that increases the returns on investment because: more educated people tend to be more efficient investors; educated individuals are more likely to have access to financial education, thus to have higher financial literacy levels; education can provide key social contacts to those who are likely to offer important information, assistance, and referral for more efficient investments.

Although women have more freedom and power than before, they are still disadvantaged in many aspects of life. They are deprived of equal access to capital and education in both business and social sectors. Despite repeated efforts made by governments, non-governmental organizations and multilateral development agencies, majority of women in the 
developing world are still relegated to micro-enterprises, informal tasks, suffer cultural prejudices and economic alienation which have serious implications on their financial status. Some of the factors pointed out as negatively impacting women's empowerment include; lack of access to credit/finance, cultural practices, lack of adequate access to education and women's lack of knowledge about rights and laws. Research has shown that when women have economic power (control of income and capital), they gain more control over their lives, contribute directly to their children's development and thereby indirectly to their nation's income growth (UNDP, 2010).

\subsubsection{Marital Status}

Marital status has also been shown to have an effect on asset accumulation (Grinstein-Weiss et al., 2006; Wilmoth \& Koso, 2002). Marriage has also been viewed as a source of financial security and continues to be a determining factor for economic wellbeing, particularly for women (Waite \& Gallagher, 2000). The assumption that microfinance is a successful and empowering strategy for women has often been based on assessment of financial indicators. Since women are able to repay their credit with interest every month, it follows that they must be running effective small businesses and managing their domestic finances. However, financial indicators do not capture the social context in which these activities are taking place and they do not tell us who is controlling the use of credit. In response, there is a move towards culturally relevant indicators that can capture how or if women's access to credit has a positive impact on their lives (Esplen, 2007).

In many societies around the world, marriage and inheritance customs still accord husbands ultimate ownership of his wife's assets. Where women have no control over money, they cannot choose to get healthcare for themselves or for their children. In their research in Bangladesh, Yemen and Ecuador, the women were asked their own definitions and indicators of their economic empowerment. In regards to asset ownership, the kind assets were land, money, goods and animals while in education, their definition was access to and ability to deploy formal and informal education (CARE,2010). Women conceive their businesses differently from the way men do and this can have an effect on their level of commitment to investment. This may be due to different socialization experience which might shape the strategic choices they make (Langowitz \& Minniti, 2007).

Most consumers of rural financial services in Ghana are small or very small business owners operating in the informal sector. A majority of these enterprises are women owned and operated and about three-quarter of Ghanaian households depend on these enterprises for at least half of the household's income. However, gender and cultural taboos dictate the type of business activities women can engage in. Their enterprises are a one person business with a start-up capital of less than 100 dollars, 90 percent are started with personal savings rather than with loans. Women tend to operate the more traditional and usually low-income businesses such as dressmaking, and retail trading while 95 percent of owners are illiterate and have inadequate business skills (IFAD, 2000).

\subsubsection{Household Size}

Using the OLS method, Orbeta (2006) estimated a saving function using income and number of children as dependent variables. Innovations for Poverty Action (2010), highlights the importance of differences of opinion within the household for making financial decisions? In this study, married couples in rural Kenya were given the opportunity to open joint and individual bank accounts at randomly assigned interest rates. Researchers assessed if couples with different preferences worked together to save in the highest return account, or if these differences led to poor financial choices. Results indicated when savings preferences in the household diverged, individuals were more likely to prefer individual accounts, and made less efficient financial decisions.

Savings has the economic advantage of ability to access loans especially in micro-credit. Commitment to savings positively impacts self-perception of saving behavior and could result in higher bargaining power over withdrawal decisions for women. Women's participation in micro-credit programmes lead to them having greater access to financial resources and freedom of mobility (Pitt et al, 2006). According to Browning (1995), households save owing to the following reasons: To build up a reserve against unforeseen contingencies... (the precautionary motive); to provide for an anticipated future relationship between the income and the needs of the individual... (the life-cycle motive); to enjoy interest and appreciation..." (the intertemporai substitution motive); to enjoy a gradually increasing expenditure... (the improvement motive]; to enjoy a sense of independence and the power to do things, 'though without a clear idea or definite intention of specific action... (the independence motive);to secure a masse de manoeuvre to carry out speculative or business project... (the enterprise motive); and to accumulate deposits to buy houses, cars and other durables (the down payment motive).

\subsection{Women Economic Empowerment and Saving}

Until recently, measurement of financial inclusion around the world has focused on density indicators, such as the number of bank branches or ATMs per capita. While these indicators made it possible to obtain basic provider-side information on the use financial services, relatively little has been known until recently about the global reach of the financial sector - the extent of financial inclusion and the degree to which groups such as the poor and women are excluded from formal financial systems (World Bank Report, 2011).

\subsection{Factors Affecting Savings}

Level of Income may influence the total amount of savings at any given time. As income falls, an individual attempts to maintain the present standard of living and in so doing, the 
proportion of consumption spending increases and total savings diminish. Personal savings will therefore be eliminated when income is drastically reduced and the individual may also spend accumulated savings rather than further reduce consumption spending (Ronald \& Edgar, 2003).

Savings and loan schemes are important tools for the empowerment of low income earners, most of whom are women. Through such schemes, they obtain affordable capital for investment in small and medium enterprises to develop livelihoods, improve family well-being and accumulate savings. The returns obtained from such business enterprises also enable the women to acquire production factors such as land, equipment, skills and business premises for sustained economic empowerment (Rambo, 2012). For some advocates, savings programmes are seen as more important than credit. Savings programmes risk becoming the next 'magic bullet' for those skeptical about credit. For many women, savings facilities are as important in increasing amounts of income under their control as are loans (Mayoux, 2006).

Spencer (2008) found that most women are also in the habit of setting up separate savings accounts where they put some money over a period of time. These small amounts end up being big amounts which can be used for investing purposes. Mayoux (2009) confirms that these design savingsled programs can increase women's financial management, and risk mitigation. Individuals save through simple informal savings mechanisms such as savings and loans clubs or nonfinancial saving such as property or livestock.

\subsection{Conceptual Framework}

Figure 1. Conceptual Framework.

\section{Research Methodology}

The study used the descriptive design. A descriptive design gives a detailed description of the nature of phenomena and examines actions as they were or as they happened without treatment to the variables (Kothari, 2004). The design was selected because it is recommended for determining the nature of prevailing conditions or relationships and practices as they existed (Wiersma \& Jurs, 2005). The target population of the study considered all registered women farm produces retailers at the Nakuru Main Market. The study divided the respondents into two subgroups from which a sample proportionate to size was selected. Proportional sampling ensures the subgroups in the population are well represented in the sample. A sample of 65 women farm output retailers was chosen using StratifiedSampling procedure suggested in Gupta and Gupta (2001). Simple random sampling method was then used to select those who actually took part in the study. The study collected data using a structured questionnaire which was administered by the researcher.

Tromp (2006) argued that researchers' administered questionnaires are preferred for survey studies as it gives room for clarification and guidance to the respondents in the course of data collection. The instrument contained both closed-ended items of the Likert type and open-ended items. The Likert Scale items were scored using a 5 point scale; Strongly Disagree (1), Disagree (2), Undecided, (3) Agree (4), Strongly Agree (5). Before data was collected, the researcher obtained authorization letter from the university that was used to gain access to the respondents. A pilot test was undertaken from samples in a different location from the study site to ensure the reliability and validity of the research instrument.

The questionnaires were coded using SPSS and Cronbach Alpha method which was computed and compared with the threshold value of 0.7 . an overall value of 0.748 was obtained which implied that the research instrument was reliable. Descriptive statistical techniques were used; frequencies, percentages and standard deviations. Correlation analysis was used to determine the relationship between the independent variables and the dependent variable (savings). Regression analysis was then used to test the effect of economic empowerment on women farm produce retailers savings. The findings of the study were presented using tables accompanied by result interpretation. The study was guided by the following multiple regression model;

$$
Y=\beta_{0}+\beta_{1} X_{1}+\beta_{2} X_{2}+\beta_{3} X_{3}+\varepsilon
$$


Where:

$\mathrm{Y}=$ the dependent variable (savings)

$\beta_{0}=$ the constant

$\beta_{1}=$ Coefficient of the independent variable

$\mathrm{X}_{1}=$ Access to credit

$\mathrm{X}_{2}=$ Access to income

$\mathrm{X}_{3}=$ Government/NGOs interventions

$\varepsilon=$ error factor

\section{Findings Discussion and Recommendations}

\subsection{Findings on Women Farm Output Retailers Access to Credit}

The study sought response on Women Farm Output Retailers Access to Credit. The results were as presented in table 1 .

Table 1. Means and Standard Deviation of Items on Women Farm Output Retailers Access to Credit.

\begin{tabular}{lll}
\hline Statement $\mathbf{n}=\mathbf{6 5}$ & Mean & Std. Deviation \\
\hline $\begin{array}{l}\text { I have adequate information on available } \\
\text { credit facilities }\end{array}$ & 2.28 & 0.99 \\
$\begin{array}{l}\text { Most credit providers do not have the } \\
\text { products that I require }\end{array}$ & 2.94 & 1.01 \\
$\begin{array}{l}\text { I have access to credit application forms } \\
\text { whenever I need them }\end{array}$ & 3.18 & 1.07 \\
$\begin{array}{l}\text { The credit application form are easy to fill } \\
\text { I rarely meet terms and conditions set by } \\
\text { credit providers }\end{array}$ & 2.68 & 1.10 \\
$\begin{array}{l}\text { My application for credit is usually processed } \\
\text { with a reasonable period of time }\end{array}$ & 2.09 & 0.81 \\
\hline
\end{tabular}

\begin{tabular}{lll}
\hline Statement $\mathbf{n}=\mathbf{6 5}$ & Mean & Std. Deviation \\
\hline $\begin{array}{l}\text { I am never given the total amount of credit } \\
\text { that I applied for }\end{array}$ & 3.11 & 1.09 \\
$\begin{array}{l}\text { I find the cost of credit (interest and } \\
\text { processing cost) to be too high }\end{array}$ & 1.82 & 1.03 \\
$\begin{array}{l}\text { Most Credit providers offer very flexible } \\
\text { credit repayment terms }\end{array}$ & 2.45 & 1.08 \\
\begin{tabular}{l} 
Access to credit index \\
\hline
\end{tabular} & 2.56 & 0.51 \\
\hline
\end{tabular}

\subsection{Women Farm Produce Retailers Mean Monthly Income}

The study sought respondents' opinion on Women Farm Produce Retailers Mean Monthly Income. The results were as presented in table 2 .

Table 2. Women Farm Produce Retailers Mean Monthly Income.

\begin{tabular}{llll}
\hline Source of Income & N & Mean & Std. Deviation \\
\hline Business & 65 & 8743.08 & 4952.78 \\
Farming (crops \& livestock) & 4 & 2500.00 & 577.35 \\
Investment (rent, shares etc) & 4 & 3025.00 & 2652.51 \\
Spouse & 6 & 2666.67 & 1080.12 \\
Others & 1 & 2000.00 &. \\
Estimated monthly income & 65 & 9360.00 & 4828.13 \\
\hline
\end{tabular}

\subsection{Findings on Access to Governmental/NGOS Interventions}

The governmental/NGOs interventions as perceived by the women farm produce retailers was measured using nineteen (19) statements in the questionnaire. The response to the 19 items was transformed into an aggregate score Government/NGOs Interventions. The findings were as presented in table 3 .

Table 3. Findings on Access to governmental/NGOs interventions

\begin{tabular}{|c|c|c|}
\hline Statement $N=65$ & Mean & S.D. \\
\hline The government has policies in place that ensure that women are not discriminated against & 2.60 & 1.21 \\
\hline The government has in place policies that give women equal opportunities to education & 2.85 & 1.26 \\
\hline $\begin{array}{l}\text { The policies put in place by the government has make it possible for women to improve their economic status in society as they can } \\
\text { on land, inherit their husbands properties }\end{array}$ & 2.52 & 1.08 \\
\hline $\begin{array}{l}\text { The policies (access to education, leadership own property) put in place by the government has make it possible for women to } \\
\text { improve their social status in society }\end{array}$ & 2.92 & 1.28 \\
\hline The government has created a conducive environment for business by ensuring that all its citizens are safe at all times & 3.08 & 1.20 \\
\hline The infrastructures put in place by the government has assisted women to progress economically & 2.91 & 1.21 \\
\hline The level of education of women in business has improved due to support from stakeholders like Government and NGOs & 2.63 & 1.05 \\
\hline The Government and NGOs have assisted women in business acquire the necessary skills and technical expertise & 2.58 & 1.07 \\
\hline $\begin{array}{l}\text { Business women have the technical expertise to develop business proposals as a result of training and support from the Government } \\
\text { and NGOs }\end{array}$ & 2.35 & 1.01 \\
\hline Business women have financial management skills as a result of training from the Government and NGOs & 2.63 & 1.11 \\
\hline Women in business are able to prepare their budgets because of the support from the government and NGOs & 2.83 & 1.07 \\
\hline $\begin{array}{l}\text { Most business women are able to make sound decisions since they have been given the relevant training by the Government and } \\
\text { NGOs }\end{array}$ & 2.35 & .84 \\
\hline $\begin{array}{l}\text { The ability of women to raise capital to start/run their business has improved due to the support from government and NGO (loans, } \\
\text { tenders) }\end{array}$ & 2.29 & 1.31 \\
\hline The government and NGOs provide women in business with affordable credit facilities & 2.71 & 1.10 \\
\hline The Government and NGO's encourage women to have a steady income through self-employment & 3.41 & 1.16 \\
\hline The Government and NGOs encourage women to save & 3.48 & 1.08 \\
\hline The Government and NGOs encourage women to abandon retrogressive cultural practices which grant all their assets to the husband & 3.23 & .98 \\
\hline The Government and NGOs encourage women to engage in businesses which their culture and traditions consider as taboos. & 2.38 & .91 \\
\hline Access to government/NGOs interventions Index & 2.78 & .63 \\
\hline
\end{tabular}




\subsection{Government/NGOS Interventions and Women Savings}

Correlation analysis was conducted to determine the relationship between Government/NGOs Interventions and Women Savings. The findings were as presented in table 4.

Table 4. Government/NGOs Interventions and Women Savings.

\begin{tabular}{llll}
\hline & Estimated & $\begin{array}{l}\text { Access to } \\
\text { monthly } \\
\text { saving }\end{array}$ & $\begin{array}{l}\text { government/NGOs } \\
\text { interventions }\end{array}$ \\
\hline & $\begin{array}{l}\text { Pearson } \\
\text { Correlation }\end{array}$ & 1 & 0.126 \\
$\begin{array}{l}\text { Estimated monthly } \\
\text { saving }\end{array}$ & p-value & & 0.356 \\
& $\mathrm{~N}$ & & 65 \\
$\begin{array}{l}\text { Access to } \\
\text { government/NGOs } \\
\text { interventions }\end{array}$ & $\begin{array}{l}\text { Pearson } \\
\text { Correlation }\end{array}$ & .126 & 1 \\
\hline
\end{tabular}

\subsection{Economic Empowerment and Savings}

Regression analysis was conducted to relate Economic Empowerment and Savings. The findings were as presented in table 5 .
Table 5. Regression Coefficients of Economic Empowerment and Savings.

\begin{tabular}{|c|c|c|c|c|c|}
\hline \multirow{2}{*}{ Model } & \multicolumn{2}{|c|}{$\begin{array}{l}\text { Unstandardized } \\
\text { Coefficients }\end{array}$} & \multirow{2}{*}{$\begin{array}{l}\text { Standardized } \\
\text { Coefficients } \\
\text { Beta }\end{array}$} & \multirow{2}{*}{$\mathbf{T}$} & \multirow{2}{*}{ Sig. } \\
\hline & B & $\begin{array}{l}\text { Std. } \\
\text { Error }\end{array}$ & & & \\
\hline (Constant) & -452.096 & 358.532 & & -1.261 & .213 \\
\hline $\begin{array}{l}\text { Estimated monthly } \\
\text { income }\end{array}$ & .029 & .013 & .283 & 2.218 & .031 \\
\hline $\begin{array}{l}1 \begin{array}{l}\text { Access to credit } \\
\text { index }\end{array}\end{array}$ & 271.373 & 131.101 & .288 & 2.070 & .043 \\
\hline $\begin{array}{l}\text { Access to } \\
\text { government/NGOs } \\
\text { interventions }\end{array}$ & -28.658 & 113.368 & -.035 & -.253 & .801 \\
\hline
\end{tabular}

\subsection{Economic Empowerment and Savings}

Regression analysis on Economic Empowerment and Savings revealed the following factors.

Table 6. The Regression Model Summary of Economic Empowerment and Savings.

\begin{tabular}{lllll}
\hline Model & $\mathbf{R}$ & $\begin{array}{l}\text { R } \\
\text { Square }\end{array}$ & $\begin{array}{l}\text { Adjusted R } \\
\text { Square }\end{array}$ & $\begin{array}{l}\text { Std. Error of the } \\
\text { Estimate }\end{array}$ \\
\hline 1 & $0.421^{\text {a }}$ & 0.177 & 0.130 & 454.960 \\
\hline
\end{tabular}

Table 7. Table of Coefficients.

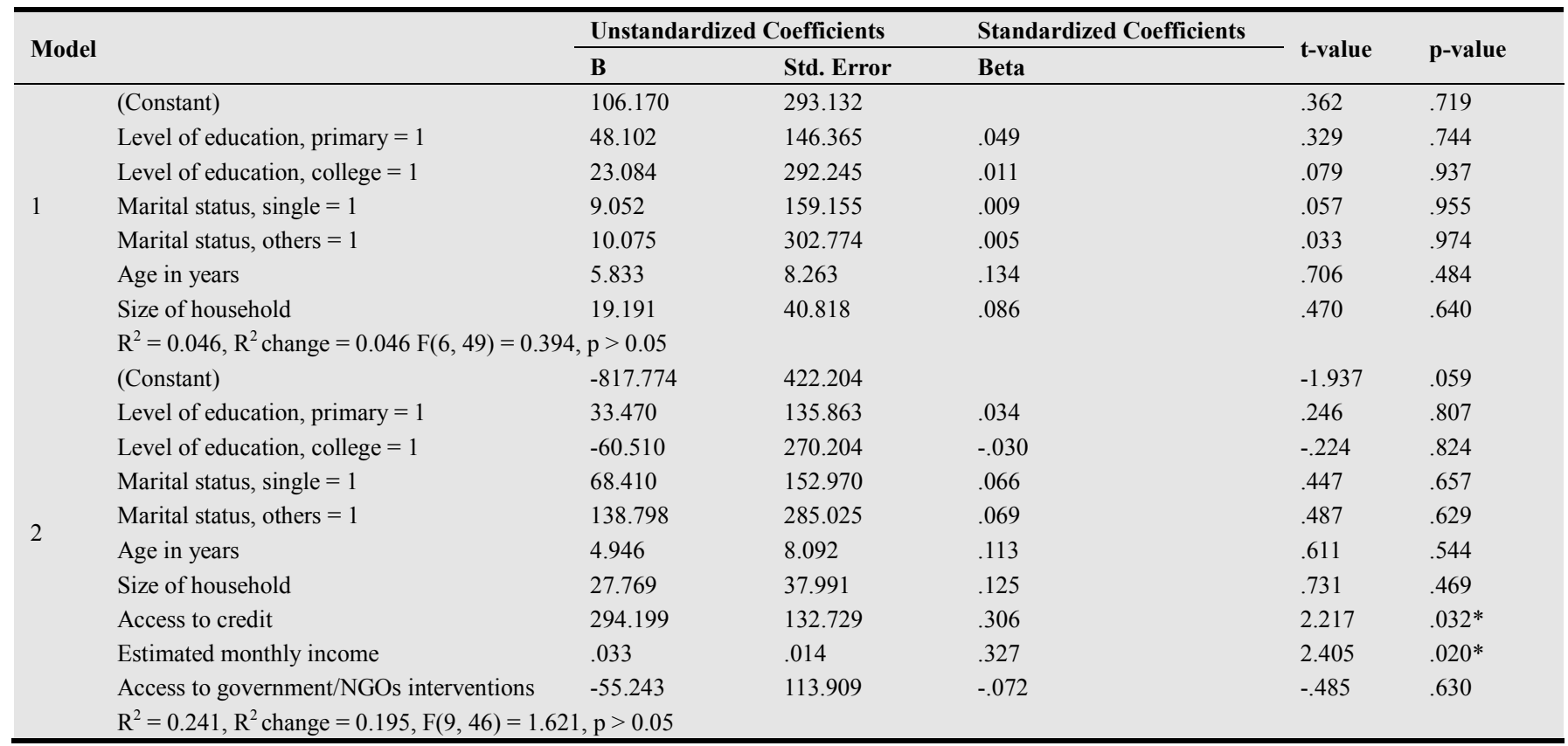

The results show that R-square is 0.177 in table 6 , this means that economic empowerment as measured by access to credit, income and government/NGOs interventions is $17.7 \%$ effective in predicting savings of the women farm produce retailers. This implies that other factors are the major contributors in influencing savings. There was need therefore to conduct further analysis by examining the effects of the moderator variables; age, level of education, household size and marital status on the relationship between economic empowerment and savings. The results in Table 7 show that the moderator variables accounted for $4.6 \%$ of the variations in savings and their effects was not significant at the 0.05 level, $\mathrm{F}(6,49)=0.394, \mathrm{p}>0.05$. When the independent variables were added to the equation there was an improvement in $\mathrm{R}^{2}$ from 0.046 to 0.241 . The inclusion of the independent variables in the analysis led to 0.195 changes in $\mathrm{R}^{2}$. It is important to note that only two constructs; access to income, Beta $=0.327, \mathrm{p}<0.05$ and credit, Beta $=0.306, \mathrm{p}<$ 0.05 in the model 2 output made significant contribution towards the prediction of the explanatory variable. The 
independent and moderator variables combined accounted for $24.1 \%$ variations, on savings, their effect was however not significant, $F(9,46)=1.621, p>0.05$. The results of the regression revealed that the independent and moderator variables combined accounted for only $24.1 \%$ variations in the savings of the women farm produce retailers.

\subsection{Hypothesis Testing}

The first hypothesis was $\mathrm{H}_{01}$ : There is no significant relationship between access to credit and the savings of women farm produce retailers in Nakuru main market. The results revealed that the relationship between access to credit and savings is positive at the 0.05 level, $\mathrm{r}(63)=0.315, \mathrm{p}<$ 0.05 . This implies that access to credit enhances savings. The first hypothesis was therefore rejected. The second hypothesis was $\mathrm{Ho}_{2}$ : There is no significant relationship between access to income and the savings of women farm produce retailers in Nakuru main market. Results revealed that the relationship between access to income and savings is positive and significant at the 0.05 level, $\mathrm{r}(54)=0.321, \mathrm{p}<$ 0.05 . This implies that women retailers with high access to income tend to save more thus access to income positively influences savings. On the basis of these results the second hypothesis was therefore rejected. The third hypothesis was $\mathrm{H}_{03}$ : There is no significant relationship between access to Government/Non-Governmental Organizations interventions and the savings of women farm produce retailers in Nakuru main market. Results revealed that the relationship between savings and access to government/NGOs interventions was positive but not significant, at the 0.05 level, $\mathrm{r}(54)=0.126$, $\mathrm{p}>0.05$. The aggregate mean was $2.78(0.63)$ suggesting that government/NGOs intervention had moderate impact on the savings of the women farm produce retailers. The third hypothesis was therefore accepted. The fourth hypothesis was $\mathrm{H}_{04}$ : There is no significant effect of access to credit, income and Government/NGOs' interventions on the savings of women farm produce retailers in Nakuru main market. The results revealed that the $\mathrm{t}$-values of access to credit $(\mathrm{t}=$ $2.070, \mathrm{p}<0.05)$ and that of access to income $(\mathrm{t}=2.218, \mathrm{p}<$ $0.05)$ were significant at the 0.05 level. This implies that the two constructs are significant predictors of the dependent variable. However, the coefficient of access to government/NGOs interventions had a negative sign. This implies that access to government/NGOs interventions is an impediment to savings. On the basis of these results, the linear equation relating savings and the three variables of economic empowerment was:

$$
Y_{1}=-452.096+271.373 X_{1}+0.029 X_{2}-28.659 X_{3}
$$

Where $\mathrm{Y}_{1}=$ Saving

$\mathrm{X}_{1}=$ Access to credit

$\mathrm{X}_{2}=$ Access to income

$\mathrm{X}_{3}=$ Access to government/NGOs Interventions.

Economic empowerment as measured by access to credit, income and government/NGOs interventions was only $17.7 \%$ effective in predicting the women farm produce retailers' savings. There was need therefore to conduct further analysis by examining the effects of the moderator variables; age, level of education, household size and marital status on the relationship between economic empowerment and savings.

From the results, the study concluded that access to credit influences savings; access to income influences savings; access to government/NGO interventions do not affect savings; and that savings is affected by access to credit, income and government/NGO interventions combined.

This study recommended; that the women farm produce retailers be encouraged to access available credit as a way of enhancing their savings; that the government and credit providers to come up with mechanisms that make credit easy to access by reducing the cost and bureaucracies involved in processing it; that organizations that provide credit to women owners SMEs be strengthened; that interventions such as a conducive business environment that boosts women's access to regular income put in place; and that the government and NGOs should put in place policies and regulations that promote creation, growth and sustenance of activities that promote savings. Examples are attractive interest regimes on savings and programmes that improve womens' access to income. Further studies should be conducted on the relationship between the government/NGOs interventions and the womens' savings.

Further studies should also be conducted on the other factors influencing the women farm produce retailers' savings.

\section{References}

[1] Amenta, E. and Ramsey, K. M. (2010). Institutional Theory. Springer Science Business Media.

[2] Brumberg, R.L. (2004). Women and gender equity in Development Theory and Practice.

[3] CARE (2011). Women's Empowerment. www.care.org/newsroom/publications/whitepapers/Womenand-empowerment.pdf 15/11/2013

[4] Collins, D., Jonathan, M., Stuart, R., \& Orlanda, R. (2009). Portfolios of the poor: How the World's Poor Live on \$2 a Day. Princeton: Princeton University Press.

[5] Deaton, A. (2005). Franco Modigliani Life-Cycle Theory of Consumption.

[6] Diana, F., \& Lisa, K. (2011). Rural women's access to financial services Credit, savings and Insurance ESA Working Paper No. 11-07.

[7] Esplen, E. (2007). Putting Gender Back in the Picture: Rethinking Women'e Economic Empowerment (17/2/2014).

[8] Eyben, R., Kabeer, N., \& Cornwall, A. (2008). Conceptualising empowerment and the implications for propoor growth Paper prepared for OECD-DAC POVNET. Brighton: Institute of Development Studies.

[9] GoK (2005). Sessional Paper No. 2. Development of Micro and Small Enterprises for Wealth and Employment Creation for Poverty Reduction. Government Printers, Nairobi. 
[10] Golla, A.A., Malhotra, P.N., \& Mehra, R. (2011). Understanding and measuring women's economic empowerment definition, framework indicators. Washington DC: International Centre for Research on Women.

[11] Gupta, S.P., \& Gupta, M.P. (2001). "Business Statistics,” Pg 539. Sultan Chand \& Sons New Delhi.

[12] Kabeer, N. (2012). Women's economic empowerment and inclusive growth: labour markets and enterprise development. $17 / 2 / 2014$.

[13] Kato, P.M., \& Kratzer, J. (2013). Empowering Women through Microfinance: Evidence from Tanzania. ACRN Journal of Entrepreneurship PerspectivesVol. 2(1).

[14] Lewis, S., \& Messy, F. (2012). "Financial Education, Savings and Investments: An Overview", OECD Working Papers on Finance, Insurance and Pensions, No.2 OECD Publishing.

[15] Mayoux, L., \& Hartl, M. (2009). Gender and rural microfinance: reaching and empowering women.

[16] Modigliani, F., \& Brumberg, R. (1954). "Utility analysis \& the consumption function: an interpretation of cross-section data", in Kenneth, K. Kurihara, ed, post Keynesian Economics, new Brunswick, NJ. Rutgers University Press pg 388-436.

[17] Negash, A. (2006). Economic Empowerment of Women. $2 / 12 / 2013$.

[18] Organization for Economic Co-operation and Development, (2010). Women's Economic Empowerment. (2/12/13).
[19] Pascaline, D., \& Jonathan, R. (2007). Savings Accounts for Rural Micro Entrepreneurs in Kenya.

[20] Rutherford, S. (2000). The Poor and Their Money. New York: Oxford University Press.

[21] Pitt, M.M., Khanker, S.R., \& Cartwright, J. (2006). Evidence from Bangladesh. Empowering women with micro-finance. Economic Development and Cultural Change, 54(4), 791-831.

[22] Sheela, M., \& Kala, N. (2013). Study on Impact Of Ngo Interventions on the Empowerment Of Women. Journal of Business Management \& Social Sciences Research (JBM\&SSR) ISSN No.2319-5614 2 (3).

[23] Tromp, D.L.A. \& Kombo, D.K. (2006) Proposals and Thesis Writing: An Introduction. Paulines Publication Africa, Nairobi.

[24] UNDP,(2013). Economic Empowerment of Women 27/8/2015

[25] UNDP,(2015). Women's economic empowerment 27/8/20

[26] Wolfgang, F., \& Borko, H. (2013). Saving is the key to future growth for Kenya (19/3/2014).

[27] Wiersma, W. \& Jurs, G.S. (2005). Designing a Research Project 22/9/2015.

[28] World Bank. (2009). Enterprises surveys: World Bank global financial development report: rethinking the role of the state of finance 2011, Washington DC. 